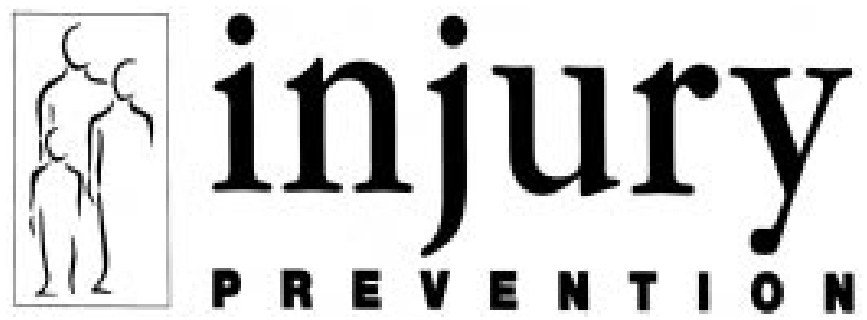

\title{
Editorial
}

\section{UNICEF's child injury league tables: a bag of mixed messages}

The report issued by the United Nation's Children's Fund (UNICEF) in February, 2001, by the Innocenti Research Centre in Florence, Italy, has attracted much attention. ${ }^{1}$ One of us (BP) promptly wrote a letter to the editor of his local newspaper deploring the tiny space it gave to the UNICEF report relative to that provided to a single case of meningitis and one possible case of Ebola virus. The letter concluded that it was evident that infectious diseases attract the public attention far more than do injuries. It went on to castigate government ministers for doing so little about injury prevention. Needless to say, the letter was watered down and lost much of its punch. Perhaps as a consequence it failed to capture the attention or arouse the ire of the Canadian federal or provincial health ministers. No doubt the same would have happened in New Zealand.

Both of us could have played up our country's relatively low ranking to try to make the point that we needed, as do other countries, a national focus for injury prevention. But, viewing other data in the same report, Canada does not appear quite so bad, whereas New Zealand does. Thus the statistics in this carefully crafted report (see book review, p 166) offer a bag of mixed messages.

Assuming the numbers are all accurate, and truly comparable (assumptions that probably should not be made with great confidence) what comparisons should we make? The data featured most prominently are the injury death rates per 100000 children ages 1-14 for 1991-95 (figure 1 in the UNICEF document). These show countries with a fivefold difference. Sweden sets the pace with a rate of 5.2 while Korea trails with 25.6. Of the 26 countries represented in this figure, the United States is fourth from the bottom, with Canada and New Zealand not far behind.

The statistics for the 1970 s, however, tell a different story. At that time, Sweden, Greece, and Spain shared top positions on the ladder, while the bottom rungs were occupied by Canada, Germany, and Mexico. In the 1970s governments and citizens of most countries were not yet aware of injuries as a health problem and had thought little about their prevention. So this date is a reasonable starting point for what should have been a race for laggard countries to try to catch up to the front runners.

Incidentally, epidemiologists (as well as other wise persons) may point out that it is usually easier to make progress when you are at the bottom than at the top. As noted above, however, both Germany and Mexico were near the bottom in the mid-1970s; 25 years later both had improved but one far more than the other.
This is why the figures that may be the most useful are those shown in table 1 , which we have newly constructed from data in the report. It ranks countries by the extent of improvement they have made since the 1970s. As the authors of the UNICEF report note, these statistics reveal "not only how far we have come in the last quarter of the 20th century, but also how much further there is to go". Germany outshines the rest with over $70 \%$ fewer child injury deaths whereas Hungary and Mexico appear to have witnessed disappointingly small improvements, each in the $32 \%$ range.

The table comprises three groups: those in the top nine, all of whom experienced $60 \%$ or greater changes for the better over the last 25 years. Here we find Germany, the Netherlands, Finland, Canada, Norway, Italy, and Japan. This is followed by a middle group with changes ranging from $50 \%$ to $60 \%$ which includes Australia, the UK, Switzerland, Belgium, France, and Ireland. Finally, bringing up the rear, with less than $50 \%$ improvement, are Greece, the United States, Portugal, and New Zealand.

Are there are any instructive patterns buried in these data? It would be gratifying if we were able to note that most of the countries that had made the greatest progress had established a coordinated national strategy or federal focus for injury prevention during this period. This is

Table 1 Rate of improvement in child injury deaths, 1971-75 to 1991-95, by country

\begin{tabular}{llllll}
\hline Country & $1971-75$ & $1991-95$ & Difference & \% Improvement & Rank \\
\hline Germany & 28.4 & 8.3 & 20.1 & 70.8 & 1 \\
Netherlands & 20.1 & 6.6 & 13.5 & 67.2 & 2 \\
Finland & 24.7 & 8.2 & 16.5 & 66.8 & 3 \\
Canada & 27.8 & 9.7 & 18.1 & 65.1 & 4 \\
Norway & 21.6 & 7.6 & 14 & 64.8 & 5 \\
Italy & 16.3 & 6.1 & 10.2 & 62.6 & 6 \\
Japan & 22.4 & 8.4 & 14 & 62.5 & 7 \\
Austria & 23.7 & 9.3 & 14.4 & 60.8 & 8 \\
Sweden & 13 & 5.2 & 7.8 & 60.0 & 9 \\
Denmark & 19.9 & 8.1 & 11.8 & 59.3 & 10 \\
Australia & 22.3 & 9.5 & 12.8 & 57.4 & 11 \\
UK & 14.3 & 6.1 & 8.2 & 57.3 & 12 \\
Switzerland & 22.5 & 9.6 & 12.9 & 57.3 & 13 \\
Belgium & 20 & 9.2 & 10.8 & 54.0 & 14 \\
France & 19.4 & 9.1 & 10.3 & 53.0 & 15 \\
Ireland & 17.2 & 8.3 & 8.9 & 51.7 & 16 \\
Greece & 13.5 & 7.6 & 5.9 & 43.7 & 17 \\
USA & 24.8 & 14.1 & 10.7 & 43.2 & 18 \\
Portugal & 31.1 & 17.8 & 13.3 & 42.8 & 19 \\
New Zealand & 23.7 & 13.7 & 10 & 42.2 & 20 \\
Spain & 13.7 & 8.1 & 5.6 & 40.9 & 21 \\
Poland & 22.5 & 13.4 & 9.1 & 40.4 & 22 \\
Czech & 19.6 & 12 & 7.6 & 38.8 & 23 \\
Hungary & 16.1 & 10.8 & 5.3 & 32.9 & 24 \\
Mexico & 29.3 & 19.8 & 9.5 & 32.4 & 25 \\
\hline
\end{tabular}


clearly the case for Sweden; somewhat true, but only recently so for Germany, but certainly not the case in either New Zealand or Canada. The national focus argument holds for Australia and it has had much greater success than its neighbour, New Zealand. However, as noted in a commentary in the Lancet, ${ }^{2}$ New Zealand took many of the same measures as Australia. Apparently, what it and Canada lacked then (and both countries lack still), was a single comprehensive national strategy, and thus, no mechanism for coordinating the efforts of the many groups dedicated to child safety. (The Lancet asked the rhetorical question: do international comparisons help? To which we reply-we certainly hope so.)

Nevertheless, buried in these data may well be better evidence showing that countries with strong, national lead organizations perform better than others whose efforts remain fragmented. To our knowledge no one has yet done such an analysis. If such a study were initiated, it would be wise to include measures of the intensity of national leadership and how long it had been in place. For example, although to its credit, the United States responded well to the injury epidemic when it created its National Center for Injury Prevention and Control, perhaps this was a case of too little too late. Even the emergence of the National Safe Kids Campaign may not be enough for such a large and complex country. In contrast, it was 1954 when the Swedish Joint Committee on Childhood Accident Prevention was established; 1962 when the Medical Commission on Accident Prevention was created in the UK; and 1982 when the latter was finally transformed into the Child Accident Prevention Trust. ${ }^{3}$

Of the many nuggets in this report, three others are worthy of comment. The figure entitled The Traffic Death League (fig 7) is revealing because in most countries traffic fatalities account for nearly half of all child injury deaths. They who control this injury best, will succeed in the end. (Although, putting on our science caps briefly, that figure would be different if another, perhaps more appropriate denominator were used, such as kilometers driven.) It would also be interesting to examine these data in light of statistics showing the ratio of private to public transport per country.
Second, the data showing the sharp differences between "rich" (that is, the OECD countries that are the primary focus of the UNICEF report) and "poorer" nations is notable, especially for traffic fatalities. As Roberts (personal communication) notes, however, perhaps more revealing would be an analysis by income disparities within countries.

Third, a point that politicians seem incapable of grasping is clearly shown in the report's figure 5: over time, injuries have risen to account for one third of all child deaths, largely because other causes of death have fallen so rapidly.

No matter how complicated the figures may be, the bottom line is clear. Assuming Sweden's rates are genuine (and there is no reason to assume otherwise) they offer a target that is achievable. This is the goal towards which all countries must strive. Our governments must be persuaded that anything that falls short of this mark reflects, first and foremost, insufficient commitment.

We wish we had more clues into what accounts for the spectacular improvement accomplished by Germanyagain assuming the figures are correct. Von Kries (personal communication) credits legislation, but none of the laws he lists differ substantially from measures taken in other, less successful countries.

Readers' are encouraged to visit the web site (www.unicef-icdc.org) and download this report. Their thoughts on this valuable document, and especially on any buried secrets for success will be welcome. We will make every effort to have them published.

Injury Prevention Research Unit,

D CHALMERS

University of Otago Medical School,

Dunedin, New Zealand

B PLESS

Editor, McGill University

Montreal, Canada

1 UNICEF Innocenti Research Centre. UNICEF: a league table of child death by injury in rich nations. Innocenti Report Card No 2. UNICEF Innocenti Research Centre, Florence, February 2001.

2 Ramsay S. Child-injury death rates - do international comparisons help? Lancet 2001;357:2001.

3 Jackson RH. The history of childhood accident and injury prevention in England: background to the foundation of the Child Accident Prevention Trust. Inj Prev 1995;1:4-6. 